\title{
Empty Promises and the Myth of Mining: Does Mining Lead to Pro-Poor Development?
}

\author{
Bonita MEYERSFELD*
}

\begin{abstract}
Mining operations in the Global South often worsen conditions for affected communities after the conclusion of the operations as compared to pre-mining conditions. This is regression, not progress, which is contrary to the narrative surrounding mining's promise of economic growth. While mining certainly brings profit, this profit does not result in social and economic development of affected communities and people living in poverty. This is the 'myth of mining' and the objective of this article is to expose this myth, identify its failings and propose a notion of 'equitable mining' that could ensure a pro-poor mining industry.
\end{abstract}

Keywords: economic development, equality, human rights law, mining, poverty

\section{INTRODUCTION}

'About 29 percent of people in the bottom billion [of the world's poorest people] live in countries in which resource wealth dominates the economy.'

For the past 200 years, the relationship between mining companies, miners, governments and affected communities has shifted only slightly. ${ }^{2}$ While mining laws have developed, both nationally and regionally, the extractives industry has not ended cycles of poverty: in many instances, the industry tends to operate in, and benefit from, impoverished contexts. ${ }^{3}$ This is contrary to the development narrative that usually accompanies largescale infrastructure projects such as mining. ${ }^{4}$ This narrative maintains that the industry's

\footnotetext{
* Associate Professor and Director of the Centre for Applied Legal Studies, University of the Witwatersrand, Johannesburg. I am grateful to Charles Young for his insights and comments and to Tammy-Lynne Bekker for her assistance. I am also grateful to my colleagues at the Wits Law School, who gave me excellent feedback at the annual law school conference.

1 Paul Collier, The Bottom Billion: Why the Poorest Countries are Failing and What Can be Done about It (Oxford: Oxford University Press, 2007) 39.

2 For a discussion of the origin of extractives and attempts at regulation to protect indigenous or local communities, see Tumai Murombo, 'Regulating Mining in South Africa and Zimbabwe: Communities, the Environment and Perpetual Exploitation' (2013) 9:1 Law, Environment and Development Journal 31, 39.

3 Louis Snyman and Robert Krause, 'Do Social and Labour Plans Belong to Communities? Clarity, Accountability and Responsiveness in the Legislative Framework', paper presented at the conference 'In Good Company? Conversations around Transparency and Accountability in South Africa's Extractive Sector' on 13 May 2015 (on file with the author). The same can be said for contexts of conflict. For a discussion of the corporate-linked exacerbation of conflict in the Democratic Republic of Congo, see Asimina-Manto Papaioannou, 'The Illegal Exploitation of Natural Resources in the Democratic Republic of Congo: A Case Study on Corporate Complicity in Human Rights Abuses' in Olivier De Schutter (ed.), Transnational Corporations and Human Rights (Oxford: Hart Publishing, 2006) 263.

4 This is often referred to as the 'social license to operate'. For a discussion of the adoption of the concept by the mining industry see John R Owen and Deanna Kemp, 'Social License and Mining: A Critical Perspective' (2013) 38
} 
proposed project will create jobs which otherwise do not exist; that there will be infrastructural development, such as roads and housing; and that mining itself will result in social and economic development, a better life. ${ }^{5}$

This narrative, however, rarely comes to fruition, especially in Africa and the Global South. ${ }^{6}$ Mines do bring jobs, but the wages often are not sufficient to meet expenses, forcing mineworkers to incur high levels of debt. As debt rises, garnishee orders become the targets for which mineworkers work. ${ }^{7}$ Jobs without adequate wages, therefore, often do not allow the majority of miners and affected communities to escape poverty. While there may be infrastructure development, as will be discussed below, houses, roads and sanitation are built for the purposes of mining and for mine management; they are rarely built for the mine workers and affected communities. ${ }^{8}$ To the extent that there are natural water resources and arable land, mining projects almost always overuse and/or contaminate the water sources and compromise arable soil. ${ }^{9}$

The reality is that mining operations often result in worse conditions after the conclusion of the operations, than existed before mining began. ${ }^{10}$ This is regression, not progress. ${ }^{11}$ While mining certainly brings profit, this profit does not result in social and economic development of affected communities. ${ }^{12}$ This is the 'myth of mining' and the first objective of this article is to expose this myth.

Having identified the myth of the development narrative of mining, the second objective of this article is to theorize a legal structure in which the negative impact of mining could be attenuated and in which mining corporations could deconstruct cycles of poverty. I refer to this as the notion of 'equitable mining'. Equitable mining embodies the notion of mining that alleviates poverty and generates a more equitable distribution

(F'note continued)

Resources Policy 29, 30. See also the analysis by Ans Kolk and Rob Van Tulder, 'Poverty Alleviation as Business Strategy? Evaluating Commitments of Frontrunner Multinational Corporations' (2006) 34 World Development 789, 798, noting that BP, Shell and Exxon Mobil all have poverty-alleviating codes of conduct but that the 'likelihood of compliance seems to remain fairly limited' and that 'monitoring is lacking in most cases'.

5 See, for example, Murombo, note 2, 33-4.

6 This is the reason for the creation by the African Commission on Human and Peoples' Rights of a Working Group of Experts on Extractive Industries, Human Rights and the Environment in 2009. African Commission on Human and Peoples' Rights, 'Resolution on the Establishment of a Working Group on Extractive Industries, Environment and Human Rights Violations in Africa', ACHPR/Res 148 (XLVI) 09 (11-25 November 2009), established at the $46^{\text {th }}$ Ordinary Session held in Banjul. Although states in southern Africa are mineral rich, they remain the poorest region. World Bank, The World Development Indicators (Washington DC: The World Bank, 2012) and UNDP Human Development Report (Washington DC: UNDP, 2013), http://hdr.undp.org/en/2013-report (accessed 21 July 2016).

7 See, for example, Khadija Pate, 'Fraudulent Garnishee Orders and SA's Poorest of the Poor', Daily Maverick (25 June 2015) 1; Malcolm Rees, 'Marikana Burst the Unsecured Lending Bubble, How a National Tragedy Exposed a National Evil', Moneyweb (16 August 2013); Chantelle Benjamin, 'Garnishee Abuse Is Order of the Day' Mail and Guardian (25 October 2013).

8 See Centre For Applied Legal Studies, Marikana: The Lived Reality, a film by the Centre for Applied Legal Studies, http://www.wits.ac.za/academic/clm/law/cals/newcalssite/16869/rule_of_law.html (accessed 21 July 2016).

9 Ibid, where these violations are poignantly related. Murombo, note 2, 36, noting the extent of land, air and water pollution as a result of mining operations-all of which lead to severe human rights violations. It is not unusual for mining companies to operate in South Africa and other jurisdictions without water-use licenses.

10 Murombo, note 2, 37-8.

11 William F Laurance et al, 'Predatory Corporations, Failing Governance, and the Fate of Forests in Papua New Guinea' (2010) Policy Perspective 95, 98, noting 'deficiencies in human welfare, with mean incomes, adult literacy, and its Human Development Index (HDI) all declining in recent years'.

12 For an extensive discussion of the link (or otherwise) between multinational corporations and poverty, see Kolk and Van Tulder, note 4, 792. 
of the profits for all those involved in the mining project. From a normative point of view, it is a point of great debate whether corporate actors have purely negative duties (the 'do no harm' principle elaborated by Professor John Ruggie ${ }^{13}$ ) or both negative and positive duties, namely, the obligation to advance socio-economic rights of impoverished persons. ${ }^{14}$ While I am of the view that the distinction between positive and negative obligations is ultimately a false one, ${ }^{15}$ I do not engage this debate in this article, partly because mining corporations themselves often identify their responsibility as contributing to local economic development and not only as refraining from harming communities and the environment. ${ }^{16}$ Within this context where mining companies themselves admit that they have positive social obligations, this article proposes how this can be achieved.

The proposed theory has three concepts, which, I argue, are prerequisites for equitable mining. The first concept is 'equal negotiating power', rooted in contract law, under which affected communities and workers should have equal negotiating power and be capable of reaching meaningful consensus on how mining will manifest. The second is the principle of 'social beneficiation', which requires that the extractives project yields profits that remain local and are more equally distributed amongst all the essential partners in mining. The third is the principle of a 'regional social and environmental impact assessment', where the impact — and potential—of mining is assessed not on a mine-by-mine basis but on a regional basis, looking at the cumulative effect of mining operations as a whole in a particular area. Unlike the first two prerequisites, this principle requires a combined effort of both government and corporate entities. This principle demands that mining as development is not understood as the operation of a single mine but rather the structure of mining operations throughout a particular region. The importance of the government's role in this cannot be overstated. However, I do not focus on government given that governments have been the subject of this issue more than corporations. ${ }^{17}$

\footnotetext{
13 Human Rights Council, 'Guiding Principles on Business and Human Rights: Implementing the United Nations' “Protect, Respect and Remedy” Framework', A/HRC/17/31 (21 March 2011), Principle 13.

14 See Abby Ghobadian, Kevin Mondey and Carola Hillenbrand, 'Corporate Responsibility Research: Past-PresentFuture' (2015) 40:3 Group and Organisation Management 271, 283 and in general, David Bilchitz, 'Do Corporations have Positive Fundamental Rights Obligations?' (2010) 125:1 Theoria 1.

15 For a discussion of the anomalous distinction between positive and negative rights, see Bonita Meyersfeld, Domestic Violence and International Law (Oxford: Hart Publishing, 2010) 213.

16 Extensive evidence is available at http://business-humanrights.org. See, for example, the claims of Norwegian oil and gas company, Statoil, which claims the integration of respect for human rights and the adoption of the Universal Declaration of Human Rights into its business model: 'Statoil Annual Report 2011', http://www.statoil.com/ annualreport2011/en/sustainability/society/humanrights/Pages/HumanRights.aspx (accessed 21 July 2016). Statoil was sued by one of its former human rights advisors for making false representations about its human rights commitments. See Paul Hoffman and Michael Seplow, 'Human Rights Advisor Sues Norwegian Oil Company Over False Representations About its Commitment to Respecting Human Rights', (17 August 2010) http://business-humanrights. org/en/statoil-lawsuit-re-human-rights-advisor (accessed 21 July 2016). The moral argument that corporations are responsible for economic development is made by Tom Sorell, 'Project Financing in Developing Countries, New Corporate Social Responsibility, Human Rights, and Multinational Corporations' (2008) 5 Essex Human Rights Review 6. The historic rationale for mining companies identifying their 'social license' to operate is discussed by Owen and Kemp, note 4, 29. In addition to Statoil, see BHP Billiton: 'We recognise the importance of creating lasting economic benefit for our communities. A focus on sustainability underpins all of our investments in community economic development'. BHP Billiton, 'Building vibrant economies as foundations for the future', http://www.bhpbilliton.com/ home/society/ourcontribution/Pages/Economic-Development.aspx (accessed 21 July 2016).

17 Centre for Applied Legal Studies, Structures of Governance: Enhancing or Impeding Environmental Justice? The Mapungubwe Case Study (Johannesburg: CALS, 2014), https://www.wits.ac.za/cals/our-programmes/environmentaljustice/ (accessed 21 July 2016).
} 
These concepts, if adopted, could result in equitable mining, which, although still harmful, may result in fewer human rights violations and advance economic growth for people living in poverty. Based on this theory, the developmental promise of mining may inch away from mythology towards reality.

The article, therefore, has two main parts. I first identify the competing narratives that characterize the mining industry, and attempt to illuminate the reasons for the disjuncture between the views of mining companies, versus the views of those employed and affected by the mining industry. I will then examine a case study (namely, Lonmin's operations at Marikana) to evidence the way in which mining promises, and mining realities, usually do not align. Having established the way in which mining operations can be harmful in exacerbating poverty, notwithstanding promises of comprehensive development, I discuss the aforementioned three preconditions, which would be necessary to ensure that mining promises become a reality. These are the notions of equal contractual negotiations, social beneficiation and regional impact assessment, respectively.

\section{Competing and False Mining Narratives}

\section{A. Different Notions of Successful Mining}

It is trite that the infamous 'resource curse' results in high levels of poverty in mineralrich states. ${ }^{18}$ Why does this anomaly-of mineral wealth coexisting with social poverty-occur? One of the key impediments to the development of the states where the extractives industry operates, is the seemingly intransigent gap between the vision of the miners versus the vision of the mine management about extractives. Mine management, major corporate shareholders, directors and advisers speak the language of profit, production and a healthy corporate entity. ${ }^{19}$ On the other hand, miners, mine affected communities and civil society speak the language of human rights, labour rights, equal participation in the benefits of mining, reward for work and decent monetary and social wages and, at times, nationalization. ${ }^{20}$ Both these sets of values are important and are not at all inconsistent with a stable extractives industry. Nevertheless, the two paradigms remain at polar opposites, where the language of profit maximization exists at the one end of the spectrum and the language of nationalization fuelled by the continued plight of communities at the other. ${ }^{21}$ The politicization of the two extremes has the potential to derail the mutually valued project of a robust economy.

So how can such seemingly reasonable positions co-exist? The point of disjuncture between the two narratives lies in understanding what constitutes 'successful mining'. The corporate theory of a successful extractives industry is one that yields a significant profit. That profit must come back to the corporation, its investors and its shareholders. ${ }^{22}$

18 See generally Collier, note 1.

19 For a critique of this position, see Bilchitz, note 14.

20 For a discussion of the notion of a 'decent' wage, see Kolk and Van Tulder, note 4, 792.

21 See Owen and Kemp, note 4, 31, noting the different expectations between mining companies and stakeholders as to what is 'necessary or desirable' for development. This is also discussed by Murombo, note 2, 33, noting the move towards indigenization in Zimbabwe due to the failure of the extractives industry to alleviate socio-economic rights violations.

22 Murombo, note 2, 36. 
This vision does not, at its core, include the objective of social upliftment. While the narrative of mining promises economic development and growth, it is not a core goal of mining that such growth and profit will either reach or enrich indigent communities. ${ }^{23}$ Indeed, the language of social development (or social license to operate) often masks the actual conduct of mining corporations, conduct which stands in stark contrast to corporate development claims. ${ }^{24}$ In reality, a successful extractives industry often relies on poverty and impoverished communities. The truth is that mining may indeed yield a profit but it does not shift structures of poverty - a claim the mining industry often makes when promising 'jobs and better lives'. 25

On the other hand, for mineworkers and affected communities, a successful extractives project is one that pays a wage that extricates them from the status quo of poverty and preserves or rehabilitates the environment in which mine-affected communities live. ${ }^{26}$ There are very few jurisdictions where the cycle of poverty is broken by mining. Mining may bring jobs and wages but such wages, particularly in the Global South, are not able to meet the demands of an individual's living expenses. So how did such a person live before? Generally the individual may have had access to arable land and subsistence farming, either from the sending community (i.e., other communities from which mine workers hail) or the area in which the mining is taking place. $^{27}$ In other words, either the mine worker leaves her/his home where there is poverty but some form of livelihood, and comes to the mine; or the mine worker's land is upended by mining, making farming impossible. However, even if life on a mine is better than life before the mine, this does not mean that the individuals on the mine are living a decent life or have escaped poverty. As Nussbaum notes, 'traditionally deprived people may be satisfied with a low living standard, believing that this is all they have any hope of getting'. ${ }^{28}$ It would be unthinkable to suggest that because a person has nothing to eat, eating rotten food is acceptable. The reality, however, is that mining, either during

\footnotetext{
23 The 'risk' of losing profit is contrasted against the long-term development agenda. See Owen and Kemp, note 4, 30. This focus is referred to as an 'imbalance between financial, social and environmental dimensions of business performance, typically favoring financial outcomes'. Ghobadian et al, note 14, 282.

24 Owen and Kemp, note 4, 31.

25 This is a feature of the timber industry in Papua New Guinea: 'The rapid depletion of PNG's forests might be justified if it led to substantial economic and social benefits for the country. Unfortunately, ... income from timber operations typically produces only modest, short-term benefits to local landowners, with proceeds often being concentrated in the hands of well-connected individuals and political elites.' Laurance et al, note 11.

26 Freeman's stakeholder theory defines 'stakeholders' as groups who have a stake in the corporate entity in question, including affected communities. R Edward Freeman, Strategic Management: A Stakeholder Approach (Boston: Pitman, 1984). For a discussion of this theory in practice, see the Centre for Applied Legal Studies, Changing Corporate Behaviour: The Mapungubwe Case Study (Johannesburg: CALS, 2014) 6, http://www.wits.ac.za/files/ bilsp_112254001405415643.pdf (accessed 21 July 2016). For a critique of the Stakeholder Theory, see Elaine Sternberg, 'The Stakeholder Concept: A Mistaken Doctrine', Foundation for Business Responsibilities, Issue Paper No. 4 (November 1999), http://ssrn.com/abstract=263144 (accessed 24 July 2016).

27 See, for example, the description of the purchasing of timber rights in Papua New Guinea. Laurance et al, note 11, 96, describing villagers who sell timber rights in exchange for school fees or health services 'although this exchange has often been less than socially equitable'. Mining in South Africa historically has its roots in compelling subsistence farmers into the mining sector, through a bracket of taxes for which self-sustaining communities had to work. See in general the work of Charles Van Onselen, The Seed is Mine: The Life of Kas Maine, A South African Sharecropper, 1894-1985 (London: Hill and Wang, 1996) and Charles Van Onselen, The Small Matter of a Horse: The Life of 'Nongoloza' Mathebula, 1867-1948 (Johannesburg: Ravan Pr of South Africa, 1985).

28 Martha Nussbaum, 'Women and Equality, the Capabilities Approach' (1999) 138:3 International Labour Review 240.
} 
the life of a mine or thereafter, destroys the possibility of individual and communal thriving. Pogge explores this concept in the mining sector, noting:

Even if there is nothing wrong with employing, on extremely ungenerous terms, someone who has other reasonable options, it may be seriously wrong to employ someone who, because of his religion or skin color, cannot find another job. By paying such a person half of what persons of different faith or color get paid ... the corporation would be taking advantage of an injustice. ${ }^{29}$

Of course, poverty is not solely the problem for corporations to address. There is a significant role for the government. While I address this briefly below, I do not focus on the role of governments in eradicating poverty in the context of mining for three reasons. The first is because this has been extensively covered in the literature. ${ }^{30}$ The second is because the role of government often eclipses the obligations of mining companies. ${ }^{31}$ In the context of my argument that the developmental promises of the mining industry are a myth, I therefore focus on the corporate side of poverty exacerbation. Finally, government, simply, is not always so powerful. The need of developing economies to attract foreign direct investment, usually results in government conduct that may not be in the best interests of affected communities. ${ }^{32}$ A classic example of this is the accession of developing state to stabilization clauses, which immunize the investing corporation from any changes in local laws that might have an economic impact on the project in question. ${ }^{33}$ The government, therefore, is not always the supposed free agent, able to use mining to break cycles of poverty. So while government agents are absolutely part of the problem of failed development projects, ${ }^{34}$ the 'blame game' should not eclipse the role of corporate actors, and it is this latter role on which I intend to focus this discussion.

In understanding the competing narratives, my objective in this article is a modest one: it is not to argue that mining corporations should be doing the job of governments. Nor is it to tackle the extremely fraught question of whether the model I propose is sufficiently lucrative for mining to continue. Rather, my objective is to expose the fabrication of mining companies' developmental narrative and reveal the contradiction that often is at the heart of the mining project's engagement with impoverished communities and contexts. My objective is to expose the development myth of mining and to argue that it is rare that impoverished communities are better off after the completion of mining than they were before the mining operations began. ${ }^{35}$ This is not development and it is not in keeping with the promises in many narratives made by the mining industry.

29 Thomas W Pogge, 'Severe Poverty as a Human Rights Violation', UNESCO Poverty Project on 'Ethical and Human Rights Dimensions of Poverty: Towards a New Paradigm in the Fights against Poverty', Philosophy Seminar at All Souls College-Oxford (March 2003) 6-7, http://portal.unesco.org/shs/en/files/4363/10980840881 Pogge_29_August.pdf/Pogge+29+August.pdf (accessed 21 July 2016).

30 Murombo, note 2, 31.

31 See, for example, 'Lonmin Annual Report and Accounts for the year ended 30 September 2012', https://www. lonmin.com/annual_report_2012/introduction/events_at_marikana.html (accessed 21 July 2016).

32 See Bonita Meyersfeld, 'Institutional Investment and the Protection of Human Rights: A Regional Proposal' in Laurance Boulle (ed.), Globalisation and Governance (South Africa: SyberInk 2011) 174.

33 Sorell, note $16,2$.

34 See, for example, the analysis by Ralph Hamann, 'Corporate Social Responsibility, Partnerships and Institutional Change: The Case of Mining Companies in South Africa' (2004) 28 Natural Resources Forum 278.

35 Collier notes: 'You would hope that the discovery of natural resource wealth would be a catalyst to prosperity, and sometimes it is. But these are the exceptions ... indeed, the surplus from natural resource exports significantly reduces 


\section{B. The Harm: Lonmin's Marikana Case Study}

An acute incident demonstrating the myth of mining is the 2012 massacre at Marikana platinum mine, run by Lonmin in South Africa. The Marikana story, described below, is selected as a case study for two reasons. The first is because the Commission of Inquiry that followed the massacre contains an abundance of information that allows us insight into the events leading up to the killings. ${ }^{36}$ This information yields a source of analysis that is quite unique in an otherwise non-transparent sector. The second is because Lonmin's undertakings to advance local economic development are clearly articulated, and the reality of the mine-affected communities demonstrates equally clearly that Lonmin's promises have not been fulfilled.

\section{The Facts}

The word 'Marikana' captured popular attention when, on 16 August 2012, 34 miners were shot while striking for better wages. The event was a profound blight on South Africa's political history and the synergies with apartheid police brutality abound. However, in the years following the massacre, discussion of Lonmin's role has been disquietingly limited. As noted above, this is not untypical of corporate malfeasance. Government liability tends to eclipse the liability of the corporate actor with the popular narrative focusing on government accountability and not corporate accountability.

So what was the role of Lonmin in creating conditions that led to the massacre? In 2012 Marikana miners, predominantly rock drill operators, went on strike to demand a wage of ZAR12,500 (about US $\$ 1,800$ ) per month for their work. The work is dangerous, highly skilled and depends on significant physical strength. At the time of the strike, the workers were earning ZAR4,000 per month (about US\$400). The figure of ZAR12,500 was not an abstract figure. It was an amount carefully calculated by the miners and their families as the bare minimum they needed to survive ${ }^{37}$ The miners were earning a salary that was a staggering less than one-third of the amount they needed to survive.

During the strike, mine workers would gather on a nearby 'koppie' (small hill). They would sit, in the cold of early spring, asking to meet with mine management. Many had left the dominant trade union, feeling disaffected and unrepresented (the dominant trade union is aligned politically with the dominant political party and many workers felt their interests were not being represented). According to South African labour law, employers are only obliged to meet with the dominant trade union. ${ }^{38}$ Lonmin management therefore had the legal right to refuse to meet the workers. And so it refused.

\section{(F'note continued)}

growth ... Over time, countries with large resource discoveries can end up poorer, with the lost growth more than offsetting the one-off gain in income provided by the rents [of mining licenses].' Collier, note 1, 38. Sorell argues that the poor land up subsidizing the rich where very large profits are made at the expense of local economic development. Sorell, note 16,2 .

36 Marikana Commission of Inquiry, Report on Matters of Public, National and International Concern arising out of the Tragic Incidents at the Lonmin Mine in Marikana, in the North West Province (2015) 94-5, 99 and 262, http://www. thepresidency.gov.za/medialib/downloads/downloads/Full\%20Report\%20of\%20the\%20Marikana\%20Commision\%20 of\%20Inquiry.pdf (accessed 21 July 2016).

37 Isobel Frye, Policy Brief 2: Towards a Decent Living Level (Johannesburg: SPII, 22 November 2013), http://spii. org.za/wp-content/uploads/2014/02/Towards-a-Decent-Living-Level-22-Nov-20131.pdf (accessed 21 July 2016).

38 See Labour Relations Act 1995 (South Africa), ss 14(1), 16(1), 18(1), 25(1)/(2), 26(1)/(2), 32(1)(a)/(b), 32(3)(a)/(b)/ (c)/(d), 32(5), and 78(b). See also Tamara Cohen, 'Limiting Organisational Rights of Minority Unions: Popcru v 
As the strike progressed, tensions began to escalate, leading to a series of murders of both mineworkers and private security officers hired by Lonmin. Lonmin was concerned about this growing instability and asked the state to intervene. On the eve of 15 August 2012, the South African police services' senior officials communicated an instruction to the police to use necessary force to bring the strike to an immediate and decisive end. The source of the instruction was alleged to be the Deputy President of South Africa-who was also a board member and major shareholder of Lonmin. ${ }^{39}$ The next day police officials surrounded the mineworkers, deployed barbed wire; shot into the captive crowd, and pursued fleeing mineworkers, shooting several in the back. ${ }^{40}$ The strike indeed ended.

Lonmin's response to the massacre was that they 'believe we did the right thing both for this Company and for South Africa in helping bring the dispute and associated violence to an end. It was easy to blame Lonmin, as some have done... We reject this accusation. ${ }^{41}$ As regards the context of poverty in which the massacre occurred, Lonmin's position is that this is a problem that goes 'beyond mining' and that 'we are rightly proud of the huge amount we have achieved in education, health, infrastructure and other areas, both for our employees and the wider community-work which has not had the recognition the dedicated teams who deliver it deserve. ${ }^{42}$ Lonmin, in other words, identified itself as an unfortunate and innocent bystander, which has done a great deal for the communities with whom they work. This is a useful example of what Owen and Kemp refer to as an 'effort to disguise or silence opposition' and to ameliorate the 'expectations gap' that exists between mining companies and their 'stakeholders'. 43

Lonmin's statements trigger two important considerations. The first is what the nature of Lonmin's legal obligation is to improve conditions for its employees and 'the wider community'. The second is what factually Lonmin did when it referred to the 'huge amount we have achieved ... for our employees and the wider community. ${ }^{44}$ I address these legal and factual questions.

\section{Lonmin's Legal Obligations}

What are the legal obligations of mining companies such as Lonmin? Section 100(2) of the Mineral and Petroleum Resources Development Act, ${ }^{45}$ read together with the Preamble to this Act, establishes a legislative framework within which the proceeds of

\footnotetext{
(F'note continued)

Ledwaba: POPCRU v Ledwaba 201311 BLLR 1137 (LC)' (2014) 17:5 Potchefstroom Electronic Law Journal 2208; Johan Kruger and Clarence Itumeleng Tshoose, 'The Impact of the Labour Relations Act on Minority Trade Unions: A South African Perspective' (2013) 7:16 Potchefstroom Electronic Law Journal / Potchefstroomse Elektroniese Regsblad 28.

39 Siphiwe Sibeko, 'Ramaphosa is Marikana accused Number One-Mpofu', ENCA (12 November 2014), http://www. enca.com/south-africa/ramaphosa-marikana-accuse-number-one-mpofu (accessed 21 July 2016).

40 Marikana Commission of Inquiry, note 36.

41 Lonmin Annual Report, note 31.

42 Ibid.

43 Owen and Kemp, note 4, 31.

44 Lonmin Annual Report, note 31.

45 Mineral and Petroleum Resources Development Act 2002 (MPRDA).
} 
mining benefit mine workers, mine affected communities, and the communities from mineworkers hail (often referred to as sending communities). ${ }^{46}$ The legislation requires every mining company to draft, in consultation with the affected communities, a Social and Labour Plan (SLP) as a precondition to obtaining a mining license. ${ }^{47}$ The SLP must ensure the equal benefit of mining, not only for mineworkers but also for the 'whole community of non-employees' who are affected by the mining project. ${ }^{48}$ The mine is required to fulfil the SLP during the entire mining project, failing which its license can be revoked. This legislation is one of the most sophisticated and sensible approaches to pro-poor economic development. The objective of the SLP system is to "promote employment and advance the social and economic welfare of all South Africans; contribute to the transformation of the mining industry; and ensure that holders of mining rights contribute towards the socio-economic development of the areas in which they are operating. ${ }^{, 49}$

Specifically, the SLP is designed to compel mining companies to use the profits from mining to: advance the education and skills of their employees, ${ }^{50}$ develop employment equity plans, ${ }^{51}$ develop a local economic development plan that would include an understanding of the impact a mine would have on the local and sending communities; ${ }^{52}$ provide infrastructure and poverty eradication projects that the mine would support in the areas in which the mine operates and the major sending areas; ${ }^{53}$ address the housing and living conditions of the mine employees; ${ }^{54}$ and address the nutrition of the mine employees. ${ }^{55}$ Most importantly, the SLP requires the mine to provide financially for the implementation of the SLP. ${ }^{56}$

It is important to reiterate that the SLP is not a corporate social responsibility initiative; it is not a voluntary assumption of a socially responsible practice. This is a legal requirement and a precondition to obtaining a mining license. Mining companies must, according to South African law, ensure economic development for all those participating in the mining project.

\section{Lonmin's Undertakings in its SLP}

Lonmin did indeed develop a SLP as a precondition to its mining license. What did Lonmin undertake to do in terms of this SLP? This question is not easily answered, not

\footnotetext{
46 For a discussion about the transformative nature of the MPRDA, see Maccsand (Pty) Ltd $v$ City of Cape Town and Others, CCT 103/11 [2012] ZACC 7, paras 3-5.

47 The required contents of a SLP are specified in Regulations 40 to 46 of Regulation 41 of the MPRDA.

48 See Louis Snyman and Robert Krause, 'In The Marikana Commission Of Inquiry Held At Centurion, Pretoria, Qualitative And Quantitative Assessment Of Lonmin's Social And Labour Plan' (2013), submissions made to the Marikana Commission of Inquiry by the Centre for Applied Legal Studies on behalf of the South African Human Rights Commission, http://www.sahrc.org.za/home/21/files/Lonmin\%20Social\%20and\%20Labour\%20Plan\%20Analysis\% 20Qualitative\%20and\%20Quantitative\%20Assessment\%20(Final)[1].pdf (accessed 21 July 2016 ) 14.

49 Regulation 41 of the MPRDA.

50 MPRDA, Government Notice R527, Regulation 46(b).

51 Ibid, 46(b)(v).

52 Ibid, 46(c)(ii).

53 Ibid, 46(c)(iii),

54 Ibid, 46(c)(iv).

55 Ibid, 46(c)(v).

56 Ibid, 46(e).
} 
least of all because Lonmin's SLP was not publically available. It was only due to the efforts of Louis Snyman and Robert Krause at the Centre for Applied Legal Studies (CALS), that the SLP came to light, following an access to information request (an analysis of Lonmin's SLP was part of CALS' submissions to the Marikana Commission of Inquiry). Snyman and Krause have analysed the $\operatorname{SLP}^{57}$ (now in the public domain) and their findings are chilling.

Lonmin's undertakings relate to employment equity; local economic development; adult basic education; and, a host of specified projects. ${ }^{58}$ As regards local economic development, (which refers to infrastructure development, poverty alleviation and income generating projects), ${ }^{59}$ Lonmin's undertaking is to 'respect the communities and nations that host our operations and conduct our business in a sustainable, socially and environmentally responsible way' ${ }^{60}$ In short, Lonmin's self-professed notion of success is 'when [o]ur employees live and work safely and experience the personal satisfaction that comes with high performance and recognition'. ${ }^{61}$ These are not definitive or tangible targets, which are necessary in order to have deliverable tangible goals; rather, these are vague values.

\section{Analysis of Lonmin's Fulfilment of its SLP}

Lonmin's aspirations, as opaque as they may be, stand in clear contrast to the events that led to the massacre where 34 miners were killed, 70 injured and 270 were arrested. Lonmin's failure to ensure local economic development is part of the dissatisfaction of the mineworkers that led to the strike. Not only did Lonmin refuse to engage with the mineworkers (although this was not a legal obligation) but they also requested the police to enter the mine and quell the strike. The strike, massacre and subsequent strikes, revealed an underbelly of poverty, disaffection and exploitation, all of which contributed to the South African Police Services opening fire on defenceless workers who had asked only to meet with mine management. How could such dissatisfaction occur when Lonmin's SLP promised to attenuate such economic and social dissatisfaction?

The truth lies in a deep disjuncture between the SLP undertaking and its implementation. Lonmin's actual education target would assist a mere 4 per cent of the population impacted by Lonmin's operations. ${ }^{62}$ This notwithstanding that most of the population of the Greater Lonmin Community (i.e., workers, mine affected communities and sending communities) has been denied the right to education. Most of Lonmin's targeted audience for education are mine employees and not affected community members. The number of community members targeted for educational

\footnotetext{
57 These documents are available at http://www.sahrc.org.za/home/21/files/Lonmin\%20Social\%20and\%20Labour\% 20Plan\%20Analysis\%20Qualitative\%20and\%20Quantitative\%20Assessment\%20(Final)[1].pdf (accessed 21 July 2016) and http://www.sahrc.org.za/home/21/files/Lonmin\%20Social\%20and\%20Labour\%20Plan\%20Analysis\% 20Qualitative\%20and\%20Quantitative\%20Assessment_ANNEXURE\%20A[1].pdf (accessed 21 July 2016).

58 Western Platinum Limited, 'Lonmin Social and Labour Plan Annual Report' (2011) 43 (Lonmin SLP).

59 Regulation 46 of the MPRDA requires local economic development to form part of a SLP. Snyman and Krause, note $48,16$.

60 'Lonmin Charter', http://www.lonmin.com/reports/2015/online_annual_report_2015/shareholder_information/ lonmin_charter.html (accessed 21 August 2016).

61 Ibid.

62 Snyman and Krause, note 48, 15.
} 
support amounts to approximately 4.6 per cent of the total population in need of adult basic education. ${ }^{63}$ The undertaking is not only extremely narrow but it is also vague and without specific targets. ${ }^{64}$

As regards employment, Lonmin's sending and affected communities have unemployment rates of 40 per cent-almost double the national average. ${ }^{65}$ Yet, Lonmin's policy is to employ people 'whenever possible'. ${ }^{66}$ The number of houses built by Lonmin translates into a 0.05 per cent fulfilment of the SLP commitment. ${ }^{67}$ Lonmin's mineworkers hail from a community in which 93 per cent of the population have no access to safe drinking water and 99 per cent have no access to clean sanitation. ${ }^{68}$ Lonmin's reporting on sanitation projects is scattered, with the limited available information demonstrating a failure of the local economic development initiatives. ${ }^{69}$

Lonmin's reasons for the failure of some of these projects are a lack of capacity and skills and a failure to find funding. ${ }^{70}$ The latter reason is an outrageous obfuscation of the SLP obligation. The obligation under the law is not to find outside investment to develop an area but to use the profits generated by the mining operation to support and develop affected and sending communities and the mineworkers themselves.

But we are not yet done with Lonmin, which has been accused of illicitly moving money out of South Africa. ${ }^{71}$ This allegation is linked to the practice of Illicit Financial Flows (IFF). States characterized by income inequality and poverty are ripe candidate for illicit financial flows. ${ }^{72}$ IFF has a dire effect on economies in which exploitative mining occurs, with the quantum of IFF exceeding the combined quantum of international aid and foreign direct investment. ${ }^{73}$ IFF is often achieved through the use of tax havens. ${ }^{74}$ Given this link, it is relevant to consider the fact that Lonmin has been associated with the utilization of tax havens and alleged tax fraud in South Africa. ${ }^{75}$ Lonmin transferred ZAR2.3 billion (approximately US $\$ 150$ million) in fees to two of its subsidiaries, one of which is located in a tax haven. ${ }^{76}$ It has been alleged that this transfer of funds was designed to insulate profit from 'financing wage demands, social labour commitments, or so that it wouldn't be absorbed in taxable income'. ${ }^{77}$

\footnotetext{
63 Snyman and Krause, note 48, 14-15.

64 Ibid, 15.

65 Ibid, 17.

66 Lonmin SLP, note 58, 59.

67 Snyman and Krause, note 48, 32.

68 Lonmin SLP, note 58, 59.

69 Snyman and Krause, note 48, 33.

70 Ibid, 33.

71 Madelene Cronje, 'Inquiry into Lonmin Fee Transfers to Tax Haven', Mail and Guardian (20 September 2014), http://mg.co.za/article/2014-09-20-inquiry-into-lonmin-fee-transfers-to-tax-haven (accessed 21 July 2016).

72 Jospeh Spanjers and Hakon Frede Foss, Illicit Financial Flows and Development Indices: 2008-2012 (Global Financial Integrity, 2015) iii.

73 Ibid, vii.

74 Ibid, ix (noting that factors contributing to IFF include 'opacity in the global financial system-comprising, among other things, tax haven secrecy, anonymous companies, and money laundering techniques-which facilitate these outflows').

75 Cronje, note 71.

76 Ibid.

77 Ibid.
} 
To be clear, this does not mean that Lonmin is either participating in IFF or tax fraud, however, it does cast a question over the extent to which Lonmin's alleged contribution to development in South Africa is fact or fiction.

The Lonmin case study is not unique. ${ }^{78}$ It is, however, a clear example of the mythology of mining-led development. I now discuss a theoretical structure that could shift mining from myth of development to one that actualizes pro-poor constructive development based on the notion of equitable mining.

\section{Prerequisites to Equitable Mining}

If we accept that mining in its current form seldom breaks cycles of poverty, what paradigm could exist to shift some of the profits of mining to impoverished communities? What we need in my view is 'equitable mining' underpinned by three factors. The first factor is the notion of equality of arms in contractual negotiation. The second is the notion of social beneficiation. The final factor is the need for regional impact assessment beyond the borders of a particular mine. I explore each of these factors below.

\section{A. Equality of Arms in Contractual Negotiation}

\section{Limits of the Current 'Consultation' Regime}

Naturally, not all power paradigms are equal but there are few as unequal as the 'negotiation' between mines and affected communities. My proposal is that all parties to the mining project should have equal power-which means the ability to consent to, or refuse a mining project - and equivalent knowledge when making decisions about and negotiating mining projects. In principle, if two listed companies are negotiating a deal, they usually have equivalent knowledge, power and resources to navigate the conclusion of a mutually agreeable contract. This is clearly not the case when mining corporations meet affected communities.

This 'negotiation' is often discussed within the framework of 'free, prior and informed consent' (FPIC). ${ }^{79}$ The concept of FPIC has suffered from several flaws in implementation. ${ }^{80}$ These flaws include: the timing of consultation; the methodology of consultation; ${ }^{81}$ and the objective of consulting versus obtaining consent (the latter

\footnotetext{
78 See, for example, the following reports: Bench Marks Foundation 'Policy Gap 9: South African Coal Mining: Corporate Grievance Mechanisms, Community Engagement Concerns and Mining Impacts' (August 2014), http:// www.bench-marks.org.za/research/policy_gap_9.pdf (accessed 21 July 2016) (describing the coal mining activities of BHP Billiton and Anglo American); Bench Marks Foundation, 'Policy Gap 8: Steel at any Cost? A Community Voice Perspective on the Impacts of ArcelorMittal's Operations in Vanderbijlpark, South Africa' (November 2013), http:// www.bench-marks.org.za/press/arcelor_mittal_report_nov2013.pdf (accessed 21 July 2016); Bench Marks Foundation, 'Policy Gap 6: A Review of Platinum Mining in the Bojanala District of the North West Province: A Participatory Action Research (PAR) Approach' (August 2012), http://www.bench-marks.org.za/research/ rustenburg_review_policy_gap_final_aug_2012.pdf (accessed 21 July 2016)); and Bench Marks Foundation, 'Policy Gap 5: Corporate Social Responsibility in the Diamond Mining Industry in Botswana-De Beers, Botswana and the Control of a Country' (2009), http://www.bench-marks.org.za/research/botswana_edit_fina_dvw.pdf (accessed 21 July 2016).

79 See, for example, Robert Goodland, 'Free, Prior and Informed Consent and the World Bank Group' (2004) 4 Sustainable Development Law and Policy 66.

80 For a discussion of some of the limitations of FPIC, see Owen and Kemp, note 4, 33.

81 The Centre for Applied Legal Studies has developed a set of standard practices of respect and interaction to guide lawyers engaging with, inter alia, mine affected communities. See the Centre for Applied Legal Studies (CALS),
} 
suggesting that a community may refuse to allow mining). As regards the timing of consultation, community engagement may occur at different times throughout the lifespan of a mining arrangement. It is seldom, however, that such consultation takes place before there has been an institutional decision by the company that the mining project in question will be both lucrative and feasible. The mining company, therefore, has made an in principle decision to proceed. It is unlikely that such a decision will change as a result of community consultation. So consultation takes place at a point on a timeline of a mining project where the most powerful players have already made a decision to proceed. $^{82}$

It is equally unlikely that, at this stage of the project, a mining company will honestly give the full gamut of information about the mining project to the affected communities. ${ }^{83}$ In addition, there is serious critique of the extent to which FPIC excludes 'marginalized' sub-groups within a community. ${ }^{84}$ This is not a new concern, especially in respect of gendered considerations and the extent to which consultation with community leaders may or may not harness the full set of considerations that affected communities may have. ${ }^{85}$ So the methodology used in FPIC is to have a superficial engagement with some representatives of affected communities, based on information that is selectively provided. This is exacerbated by other problematic aspects of this methodology, such as inadequate notice and language barriers.

For example, when Coal of Africa Ltd. (CoAL), an Australian mining company, began mining in Mapungubwe, a world heritage site, it presented a picture of development and wealth accumulation for South Africans living in poverty. ${ }^{86}$ After years of resistance from the Save Mapungubwe Coalition (a coalition opposing the mining of coal in the area), CoAL was forced to close its operations temporarily while it sourced more financing for the project. CoAL had to find more money for the project in order to be able to comply fully with the relevant mining licenses that, but for the lobbying and litigation by the Coalition, CoAL would have avoided obtaining. In other words, CoAL appeared to finance a project that it fully intended to operate without complying with the full range of license and regulatory requirements. CoAL used a practice known as 'care and maintenance' to suspend operations, even though the purpose of closure was to raise funds and not to maintain or improve the mine.

Two issues emerge. First, CoAL never told its workers that there is a practice that would allow the mine to close its doors for years at a time, sending the workers home without remuneration or a promise of a job if the mine re-opened. This would be crucial

\footnotetext{
(F'note continued)

'Community Engagement Policy’ (April 2014), https://www.wits.ac.za/media/wits-university/faculties-and-schools/ commerce-law-and-management/research-entities/cals/documents/CALS\%20Community\%20Engagement\%20Policy. pdf (accessed 21 August 2016).

82 Andrea Cornwall, 'Unpacking "Participation": Models, Meanings and Practices' (2008) 43 Community Development Journal 269, 271, discussing 'functional participation' whereby entities consult for the purpose of meeting project objectives more efficiently but only after the main decision to conduct the operations has been taken.

83 Owen and Kemp, note 4, 33, noting that without knowledge, skills and resources, poorer communities will be excluded from meaningful participation in decision-making processes.

84 Ibid. See also CALS, 'Community Engagement Policy', note 81.

85 See Bonita Meyersfeld, 'Business and Human Rights and Gender: A Legal Approach to External and Internal Considerations' in Surya Deva and David Bilchitz (eds.), Human Rights Obligations of Business Beyond the Corporate Responsibility to Respect (Cambridge: Cambridge University Press, 2013) 183, 214.

86 CALS, 'The Mapungubwe Case Study', note 26.
} 
information for an affected community and mineworkers to consider when negotiating with a mine about a potential project. Second, CoAL had evaluated the viability of the project based on the cost of mining without complying fully with the South African regulatory framework. Mining properly-and lawfully-was expensive. In all likelihood, it was too expensive to be economically viable. The development promise, therefore, was always a myth.

It is clear, therefore, that the negotiation between a mining company and, say, a bank is vastly different from the negotiation between a mining company and a mine-affected community. ${ }^{87}$ This is in no small part due to the fact that affected communities have disproportionate knowledge about the mining process. This asymmetry of information distorts the full reality of mining, thereby impeding the ability to make informed decisions.

The final, and most contentious, deficiency in FPIC is that affected communities are rarely asked to consent to mining. 'Consent' would imply that they would have the right to refuse the operations. This allows consultation to be a formal 'tick-box' operation rather than a sincere and in-depth engagement with affected communities.

Regional exchanges and strategies to ameliorate this information asymmetry and unbalanced bargaining leverage are a necessity. ${ }^{88}$ This approach is similar to the principle of participation known as 'self-mobilization', where affected communities develop their own resources and expertise to engage with external repositories of power. ${ }^{89}$ With stronger negotiating bases, the extraordinary value of human labour can better come to the fore.

\section{Addressing the Limits of the Current 'Consultation' Regime}

How can parity in negotiation be achieved? If communities who have experienced mining can engage with communities yet to be affected, this could enhance information symmetry, especially regarding the harmful impacts of mining, and equality of arms in the negotiation around mining. Of course this presupposes that mining companies are serious about the participation of affected communities in the mining project and that consultation is not an act of tokenism. ${ }^{90}$ But, as stated above, this supposition is based on the narrative of the mining companies themselves. This narrative may well be part of the mythology of mining but let us assume for the moment that this is a genuine imperative for mining companies.

Where a community is likely to be affected by a mining project, such communities should not be reliant only on the information provided by the mining company itself. If the company controls the flow of information, it is reasonable to expect that it will provide selective information that presents the beneficial aspects of the mining project. There is no incentive to talk about the possible and actual negative impacts of mining. This information asymmetry can be ameliorated if communities with whom mining companies will engage could receive information from two additional sources. The first

\footnotetext{
87 For a discussion about the principles of participation, see Cornwall, note 82.

88 See Kolk and Van Tulder, note 4, 792.

89 Cornwall, note 82, 271.

90 'Tokenism' as a form of placation is a concept developed by Sherry Arenstein, 'A Ladder of Citizen Participation' (1969) AIP Journal 216-24. See Cornwall, note 82, 270.
} 
is from social justice movements and organizations. The second and in my view, the source with greater integrity, is from communities which have already been affected by similar mining activities.

Social justice and human rights law movements are important in providing alternative information about mining projects - and in representing communities in negotiations with mining corporations-but such entities usually hail from backgrounds of professional and economic privilege. Their advice equally is going to have a particular bias, depending on the vision of a given civil society organization (CSO) in question, which might be a blanket opposition to mining. This may not necessarily be the approach an affected community would choose and an unfettered source of information is seminal to making an informed decision.

Intra-community learning exchanges, which operate as peer learning mechanisms, ${ }^{91}$ can operate as the second source of information. Unlike CSOs, the source has direct knowledge of mining and its impact on communities. Those who have experienced mining are able to relate to potential mine-affected communities what went wrong and how they could better negotiate labour and other contracts, as well as other benefits such as a contribution to local economic development from the mining company concerned. $^{92}$

However, intra-community exchanges too have their limitations. The notion of intra-community learning would not necessarily cure the problem of internal discrimination within a community. ${ }^{93}$ Nevertheless, such information exchange will raise the negotiating leverage of mine-affected communities so that they become more equal beneficiaries in the mining social contract. This enhances information, equalizes negotiation and could lead to a far more stable — and equal—extractives project.

The methodology of exchanging information must include site visits by the negotiating communities with communities who have experienced mining, where the mining operations would be of a similar size and seek to extract the same type of resources. These should include both affected communities and sending communities. Such site visits would ensure that negotiating communities understand-and see first-hand - the impact of mining on soil, water and air. It will also provide information about the nature of employment, health risks, wage negotiations, terms of employment and other information that would be useful to the negotiating communities when in negotiations with the mining company in question. This in turn can fuel their negotiations with mining companies regarding the terms of mining and post-mining closure requirements. I do not for a moment suggest that such negotiations will always be successful in persuading a mining company either not to mine or to amend its mining plan; I proffer merely that this will be the best way to attenuate the information asymmetry and create a more equitable negotiating forum.

If a mining company is serious about its commitment to social and economic development, there is no justifiable reason why it should not facilitate and indeed fund

\footnotetext{
91 This is a seminal part of the work undertaken by Louis Snyman and Robert Krause at the CALS at Wits University.

92 This model has been adopted by the CALS in its Environmental Justice Programme, https://www.wits.ac.za/cals/ our-programmes/environmental-justice/community-learning-exchanges/.

93 Meyersfeld, note 85, 214. See also Owen and Kemp, note 4, 31, noting the exclusion of certain social units from engagement and negotiation.
} 
such exchanges. ${ }^{94}$ More importantly, the company in question should take the views - and decisions_of the affected community seriously in its proposed operations. This will be not only in line with corporate language of a 'social license' to operate and but also ensure that 'decisions about development [are] made as close to those affected as possible'. ${ }^{95}$ A true commitment to respect for, and collegial, professional engagement with, affected and sending communities would be premised on a commitment to an equal relationship. This should also include the facilitation of effective legal representation for affected communities. It is only through an equal and equivalent bargaining relationship, which itself is preconditioned on symmetrical levels of knowledge and information, that meaningful bargaining can occur. Anything less is a form of exploitation and contestation, making the promise of partnering with local communities a myth and not reality.

\section{B. Social Beneficiation: Recalibrating the Value of All Mining Stakeholders}

\section{The Principle}

The second way in which the myth could become reality is through a notion of 'social beneficiation'. Beneficiation refers to the process of manufacturing raw materials in the location from which they have been extracted. ${ }^{96}$ Beneficiation is a construct that would allow the greatest benefit from the extraction process to remain localized. Rather than have the raw material shipped offshore of its source of extraction, beneficiation allows the extraction and processing to remain local, thereby generating greater localized profits, which in turn have greater impact on poverty alleviation. ${ }^{97}$

Usually, benefication is a term of art that refers to mechanization and manufacturing. But what if we adapt this principle to the notion of human labour? Should we not recalibrate the value we ascribe to the various forms of labour that comprise the mining industry?

\section{Recalibrating the Value of Work: The History of Mine Worker Valuation}

The failure to channel profits into the development of those affected by mining, reveals an accepted practice of exploitation that is hundreds of years old. It is a practice that imposes vastly different notions of pecuniary value on labour, management and ownership in the mining industry. The latter two are seen to be far more valuable than the first. This type of value system is deeply unfair and ought to be the subject of change.

The inequity is particularly stark if one considers that there are five entities that are indispensable to the extractive process. Without any one of these players, extracting mineral resources is not possible. The players are: (i) the government: as custodian or regulators of the minerals in the ground, the government is indispensable to (legitimate) extraction; (ii) financiers: the cost of mining requires the commitment of financial

\footnotetext{
94 For an argument supporting the positive obligations of corporations to foster self-organization, see Kolk and Van Tulder, note 4, 793.

95 Owen and Kemp, note 4, 31.

96 Department of Mineral Resources, South Africa, 'Beneficiation Economics', http://www.dmr.gov.za/beneficiationeconomics.html (accessed 21 July 2016).

97 Ibid.
} 
institutions, without which large-scale extraction could not occur; (iii) the mining company: mining companies have the expertise and project management experience indispensable to large-scale extraction; (iv) miners: no matter the extent of mechanization, in many forms of mining human beings will almost always be needed to go underground. Without the individual miner, such large-scale extractive mining is not feasible; and (v) the mine-affected communities, including the sending community from where workers hail and the affected community that services the mine and its workers.

Although each entity's input is indispensable to the mining project, the benefit each receives differs vastly. This is so for a number of reasons, including relative surplus or deficiency of labour, education, training, and the scarcity of skillsets. This value, however, is also determined by the imperatives of a society at a particular historic moment. The value of mine labourers was determined over 200 years ago, when the value of an individual was based on their race or gender and not on the extent to which their work was pivotal to the extraction project.

This history is necessary to understand the reason for the vastly different valuations of the work of the mine labourer and the mine manager (both of whom are, as established above, indispensable to the mining project). What informs such valuation? The valuation is partly informed by availability of labour-there are fewer mine managers than rockdrill operators. This value is also determined by the extent of education the mine manager needs to become a mine manager. But it is interesting to note what has not been considered in the determination of labour value. When it comes to negotiating the contractual terms that ascribe value to human work, we should be injecting notions of danger, life expectancy and difficulty of work, together with principles of scarcity and education, which are currently the dominant drivers of determining the value of human capital.

In truth, we need to face a hard reality: that the value of the work of a mine manager and the value of the work of a mineworker, is informed in part by the historic structures in which mining is moored. Mining operations are moored in colonial operations, where the value of one's work was determined not by the importance or gravitas of the work one did, but rather by one's race or sex. The mining sector historically ascribed no pecuniary value to the work of miners, many of whom indeed operated as slaves. ${ }^{98}$ This was not because the work of mining was not difficult but rather because the person doing that work was identified as less human. Identified, to be blunt, as black. Had the person doing that work been white, the labour would have been valued differently. ${ }^{99}$

This is akin to the feminist project of noting how household labour-and the labour performed in female-dominated industries such as teaching and nursing - are less valued than male labour. ${ }^{100}$ This is not because the work is less difficult or less valuable to

98 See S Daniels Neumark, Foreign Trade and Economic Development in Africa: A Historical Perspective (Stanford: Stanford University Press, 1964).

99 Rachel L Swarns, 'Rarity of Black-Run Businesses Worries South Africa's Leaders', New York Times (13 November 2002), http://www.nytimes.com/2002/11/13/world/rarity-of-black-run-businesses-worries-south-africa-sleaders.html?pagewanted $=$ all (accessed 21 July 2016).

100 See, for example, Nancy Fraser, 'After the Family Wage: Gender Equity and the Welfare State' (1994) 22 Political Theory 591; Erica L Groshen, 'The Structure of the Female/Male Wage Differential: Is It Who You Are, What You Do, or Where You Work?' (1991) 26 The Journal of Human Resources 457; Donald J Treiman and Heidi I 
society; but rather because the person doing the work is considered to be less capable and less valuable. This is part of a system of oppression-where black people or women (depending on the context) continue to earn less, not because their work is less valuable but because they themselves are deemed to be less valuable by the entities in society that control hierarchy. The overt structure which sustained the systems of oppression (be they racial segregation or sex segregation) have been stripped away formally, but the legacy of false attribution of value to such labour remains. The result: a mineworker-facing death on a daily basis, being subject to long-term illness and using exceptional strength and fortitude - is valued less than her/his counterpart who sits in an office and manages the operations.

At the very least, we should acknowledge that we have not included all the relevant factors in calculating the value of labour. If we did, the valuation of mineworkers' labour would be much higher than it currently is. The mining industry is embedded in structural inequality, which has led to the myopic acceptance of a very harmful status quo: where the leaders of the mining industry determine the value of all those in the extractives project; and where the mineworkers are valued at a radically reduced rate.

Appropriate valuation of work is one of the ways in which the social beneficiation of mining could occur-where the benefit of mining remains localized in the country from which the material is extracted. ${ }^{101}$

\section{Recalibrating the Value of Work: Global Economic Hegemony}

In order to truly understand why the colonial history of valuing labour persists, it is necessary to understand the global exploitative link between mining and poverty. ${ }^{102}$ As discussed above, global corporate profit from mining relies on and often exacerbates poverty, particularly in the Global South. ${ }^{103}$ Social beneficiation has to be understood within the context of the power imbalance between the Global North and Global South (with BRICS and emerging economies combining characteristics of both, i.e., that they are both the recipients of human rights violations and the perpetrators of human rights violations in other developing or least developed economies).

The harm of mining that needs to be addressed is not the Marikana Massacre or the Niger Delta devastation; it is not about collapsing mine shafts; it is not about even child labour, forced labour, displacement or disease. These are the symptoms of the harm. The harm that needs to be addressed is the fact that these tragic incidents occur regularly and largely in the Global South as a result of projects and practices designed to secure the flow of profits to the Global North.

(F'note continued)

Hartmann, 'Women, Work, and Wages: Equal Pay for Jobs of Equal Value' (1981) Committee on Occupational Classification and Analysis, National Research Council (Atlanta: National Academic Press (1981).

101 This begs the question of how the value of the work of the five sets of actors highlighted in this article should be determined. This would be a project incorporating multiple disciplines, including economists, lawyers, mining experts and sociologists.

102 The link between multinational corporations in general, including mining companies, and poverty is evidenced in 'dynamic comparative advantage' and a failure to monitor development undertakings. See Kolk and Van Tulder, note 4, 797.

103 See David Bilchitz, 'Critiquing the Normative Foundations of the GPs' in Deva and Bilchitz (eds.), note 85, 107, 124-5. See also Kolk and Van Tulder, note 4, 790. 
Within this global economic hegemony, it is interesting to note how poverty is constructed as a notion. Poverty is designated as a developmental issue, caused by deficiencies and crises in the countries in question. Poverty is not identified as a human rights violation. In the current international law regime, not having access to food is a human rights violation; not having access to water is a human rights violation; not having access to health or housing or justice - these are all human rights violations. ${ }^{104}$ But if we put them together as a cumulative, this is called 'poverty'. ${ }^{105}$ And poverty as such is not considered a human rights violation or a breach of international law.

However, poverty is not an accident. Poverty is structural and continues not because of deficiencies in the people living in poverty but because of global trade and economic regimes, political and governance policies and an entrenched inequality, which is well documented by developmental theory. ${ }^{106}$ Poverty is not only an impediment to the fulfilment of basic rights; it is also a barrier to the fulfilment of one's capabilities, one's ability to flourish according to one's abilities and one's ability to choose a life. This notion of escaping poverty is linked to the capabilities approach, developed, among others, by Amartya Sen and Martha Nussbaum. This approach asks what an individual is 'actually able to do and ... what she does, and what she is in a position to do (what her opportunities and liberties are)'. ${ }^{107}$ Crucially, this approach is not only about resources-how much money is available in a country for example — but about how those resources 'do or do not work' for an individual to flourish. ${ }^{108}$ If we accept that poverty is a structure, then we can identify, broadly speaking, winners and losers in this normative framework: the Global South battles with continued poverty (exacerbated by detrimental Bretton Woods policies), ${ }^{109}$ making such states prime targets for corporations looking for low overhead costs in poorly regulated states with high levels of impoverished (and therefore exploitable) labour. ${ }^{110}$ While free market policies have also enabled many countries in the Global South to reduce poverty, this has not ended poverty. As Pogge notes,

most people in the rich countries think of our global economic order as basically just ... We [people in the Global North] know that billions abroad are exposed to life threatening poverty. We think that we should perhaps help these people with sporadic donations, just as

104 International Covenant on Economic, Social and Cultural Rights, 993 UNTS 3 (adopted 16 December 1966, entered into force 3 January 1976).

105 Of course, poverty is a complex phenomenon caused by contributions of multiple actors and variables. My point here is to note that poverty per se is not categorized as a human rights violation under international law. This is a deficiency in international law.

106 See Amartya Sen, Development as Freedom (Oxford: Oxford University Press, 1999); Oxfam International, The Rigged Rules of Global Trade (Oxford: Oxfam International, 2014); Oxfam International, 'Pricing Farmers Out of Cotton: The Costs of World Bank Reforms in Mali', Oxfam Briefing Paper (2007). See also the Human Rights Council, 'Guiding Principles on Extreme Poverty and Human Rights', A/HRC/21/39 (18 July 2012) and the keynote address of the Special Rapporteur on extreme poverty and human rights, Philip Alston, at the Nordic Trust Fund for Human Rights and Development Annual Workshop: 'Rethinking the World Bank's Approach to Human Rights' (15 October 2014), noting that the World Bank president Jim Yong Kim, 'did not speak of the need for redistribution, nor of the need for fair and equitable taxation systems, nor about tackling international tax avoidance ... the implication of this analysis seems to be that poverty eradication can be severed from the struggle for rights...' (http://www.ohchr.org/EN/NewsEvents/ Pages/DisplayNews.aspx?NewsID=15275\&LangID=E).

107 Nussbaum, note 28, 233.

108 Ibid.

109 Guiding Principles on Extreme Poverty, note 106.

110 Meyersfeld (2011), note 32. Murombo, note 2, 33, noting that 'extractives underpin most economies in Africa'. See Thomas Pogge, World Poverty and Human Rights, $2^{\text {nd }}$ edn. (New York: Polity, 2008) 104-6. 
we should occasionally support the worst-off in our country. But few of us believe that this extensive and severe poverty, even if unavoidable, shows our global economic order to be unjust. $^{111}$

Pogge then goes on to show that '... the global economic order, imposed by wealthy societies...contribute substantially to the persistence of severe poverty., 112

It is also impossible to ignore the colonial gloss that continues to inform international regimes, which regulate this 'North-South' dyad. For example, the prime focus of international criminal law codified in the Rome Statute has been the heads of state in Africa responsible for some of the most egregious human rights violations. ${ }^{113}$ This fuels the narrative of Africa as dangerous and delinquent, with leaders who cannot be trusted to advance the interests of their people. In many instances this is true and African leaders are responsible for unspeakable human rights violations, including corruption in the mining industry. At the same time, there has been a disquieting veil drawn in front an array of human rights violations and violators that emanate from the Global North. ${ }^{114}$ The conflicts in Liberia and Sierra Leone are an example of this. Charles Taylor was rightly targeted for his involvement in fuelling the Sierra Leone conflict and financing the rebel factions. ${ }^{115}$ However, there is no mechanism to identify and hold accountable the individuals who bought the timber or diamonds, providing the funds for the war. ${ }^{116}$ The millions of dollars sent outside Liberia and Sierra Leone, often housed in banks in the Global North, remain out of reach of the citizens of these countries. As the global loan and aid machine begins to grind into effect, Liberia will be dependent on aid and loans (often with unfair repayment conditions) while its natural resource wealth remains outside the country. ${ }^{117}$

In understanding poverty, we look only at the most proximate cause-warring factions or despotic leaders - and not at who created those factions or armed them, or benefited from their control of natural resources. ${ }^{118}$ The entire global economy is replete with the biggest cover up in history: where the true demons of pain and anguish in the African continent sit as judges of our leaders and insulate their own corporate foot soldiers from any liability, either for committing human rights violations or for benefiting from and exacerbating mass poverty.

111 Ibid, 101-2.

112 Ibid, 121.

113 See Max Du Plessis, The International Criminal Court that Africa Wants (Pretoria: Institute for Security Studies, 2010), https://www.issafrica.org/publications/monographs/the-international-criminal-court-that-africa-wants (accessed 6 August 2016); and Charles C Jalloh, Dapo Akande and Max du Plessis, 'Assessing the African Union Concerns about Article 16 of the Rome Statute of the International Criminal Court' (2011) 4:1 African Journal of Legal Studies 5.

114 This is evident from the Committee of Privy Counsellors, 'Report of the Iraq Inquiry, Report of a Committee of Privy Counsellors', HC 264 (6 July 2016), commonly referred to as the Chilcot Report, http://www.iraqinquiry.org.uk/ media/246416/the-report-of-the-iraq-inquiry_executive-summary.pdf (accessed 21 July 2016). The Report finds that Prime Minister Blair's decision to deploy large-scale forces in Iraq was unlawful (p122 of the Executive Summary).

115 The Prosecutor $v$ Charles Ghankay Taylor, SCSL-2003-01-1, http://www.rscsl.org/Taylor.html (accessed 21 July 2016).

116 Although there has been an attempt to hold corporate actors responsible for their involvement in fueling the civil war: DLH lawsuit regarding the Liberian civil war, http://business-humanrights.org/en/dlh-lawsuit-re-liberian-civilwar (accessed 21 July 2016).

117 Global Witness, 'Bankrolling Brutality Why European Timber Company DLH should be held to account for profiting from Liberian conflict timber' (2010), https://www.globalwitness.org/sites/default/files/library/ bankrolling_brutality_low.pdf (accessed 21 July 2016).

118 For a discussion of the role of mining corporations in the conflict in the Democratic Republic of Congo, see Papaioannou, note 3, 263. 
In other words, it is an unequal power regime globally that allows the profits created by mine workers' labour to be exported. These profits should remain localized and such labour should lead to 'social beneficiation'. This is the corollary of the critique of partial and selective globalization, in which the flow of people across borders is smaller than the flow of trade, goods and capital flows. ${ }^{119}$ If labour is properly remunerated, mining may well enhance economic growth in South Africa, giving meaning to globalization as a form of economic development which addresses poverty. At the moment however, this is not the case.

\section{Regional Impact Assessment of Mining}

A mine's operations are not limited to the boundary of a single mine. Mining companies may operate in more than one location across a particular seam or mineral belt and their operations may have an impact on ecosystems and peoples who fall outside the four corners of a mine's precinct. This requires the notion of 'spatial planning', which 'requires that decision makers responsible for development in a particular geographical area have a comprehensive and accurate picture of the distribution of cultural, ecological, hydrological and economic value and of regional interest groups.' ${ }^{120}$

It is disingenuous to maintain that each mine should be seen in isolation. Yet, this is often how mining operations manifest. If a mining company is serious about its development role, it will look comprehensively at its own operations' impact and the impact of surrounding mines. The social and environmental impact of mining should be assessed not on a mine-by-mine basis but on a regional basis, looking at the cumulative effect of mining operations as a whole. This process demands that mining as development is not understood as the operation of a single mine but rather the structure of mining operations throughout a particular region. This exercise is one that the government ideally should undertake. However, if the narrative of mining companies is to advance development in a sustainable way, the company itself should undertake regional impact assessments, both social and environmental.

There are three reasons why this approach is a prerequisite to pro-poor equitable mining. The first is that mining companies will often operate in a scheme of a government's local economic development plan. While this may differ from state to state, an arrangement is often brokered between the mining company and the local municipality to advance local economic development (LED). LED is not about a 'donation' or isolated contributions to isolated communities. It is about co-owning the responsibility, with government, for the enhancement of an overall area, in which a mining company is operating. Development claims by a mining company, therefore, ought to operate in lock-step with local government (assuming of course that there is a representative and accountable government in place).

It is fallacious to make the claim of pro-poor development while placing complete responsibility for LED on a local government. By claiming to enhance an area, a mining company would need to approach such development in conjunction with concurrent developmental efforts by both other mining companies and the government. Only then

\footnotetext{
119 See Richard B Freeman, 'People Flows In Globalization' (2006) 20:2 Journal of Economic Perspectives 145.

120 CALS, 'Structures of Governance', note 17, 35.
} 
could one envisage a comprehensive development plan that speaks to meaningful local enhancement of service delivery, access to water, sewerage plants and the basic hallmarks of enhanced living.

This involves 'mapping and understanding the characteristics of a specified area' 121 and determining not only the direct consequences of mining in the mined area itself, but also so-called 'down stream' impacts, impacts that usually affect communities farther afield through, for example, water, soil and air contamination. These are not containable consequences and any mining project should take these variables into account if they intend to ensure LED. The failure to do so has the potential to impede already impoverished communities from the subsistence lifestyle that characterizes such communities. This is hardly LED. As Snyman and Krause note in their report on social and labour plans, true responsiveness to a mine's impact on a region requires 'notions of strategic planning that link land use and spatial development to the attainment of socio-economic goals.' 122

The second reason is that a piecemeal approach to determining a mine's impact leaves communities with nowhere to go when the promise of enriching mining is not achieved. Too often mining companies will lay responsibility for deficient development at the door of a government. The government similarly will point to the company in question as being the port of call for such failures. This is a blame-game that exculpates governments and corporations from accountability for the harm that affected communities endure. ${ }^{123}$ Of course there are myriad reasons why a developmental plan may fail, some of which truly may not be due to the mining company itself. However, it is the mining company's claim of development that, if true, would impose an obligation on it to ensure that this has content and meaning throughout the area in which it operates. As Lewis Carroll famously quipped, 'The rule is, jam to-morrow and jam yesterday-but never jam to-day'. ${ }^{124}$ Without comprehensive regional planning, economic development may become a promise of tomorrow, nothing more than a pleasant future notion, which is unreachable and destined never to materialize.

Finally, striving for a regional approach to mining ensures a far more comprehensive engagement with local knowledge of the area in which mining will operate. Ali notes the importance of accessing indigenous knowledge with reference to Articles 15 and 16 of the International Labour Organization Convention Number 169: the notion of 'total environment of the areas which the peoples concerned occupy or otherwise use. ${ }^{125}$

\footnotetext{
121 Centre for Applied Legal Studies, The Social and Labour Plan Series, Phase 1: System Design Trends Analysis Report (Johannesburg: CALS, 2015) 11.

122 Ibid.

123 Examples of the 'blame-game' include: Peter Moskowits, 'As Coal Struggles, the Blame Game Begins', Al Jazeera, (8 November 2014), http://america.aljazeera.com/articles/2014/8/11/coal-blame-game.html (accessed 21 July 2016); Martin Creamer, 'Mining's Damaging “Blame Game” Destroying South Africa', Mining Weekly (26 June 2013), http://www.miningweekly.com/article/minings-damaging-blame-game-destroying-south-africa-xstrata-alloys-201306-26; and Niren Tolsi and Paul Botes, 'Marikana: The Blame Game: A Special Report', https://laura-7.atavist.com/ mgmarikanablamegame (accessed 21 July 2016).

124 Lewis Carroll, Through the Looking Glass (London: Collins Classics, 2010) 65.

125 Saleem H Ali, 'The Ethics of Space and Time in Mining Projects: Matching Technical Tools with Social Performance' (2004) 135:4 Journal of Business Ethics, 645, 649.
} 


\section{Conclusion}

If the claim is that mining companies can and should work towards the fulfilment of economic and social rights of the people with whom they work and who are impacted by their work, what is the response of the mining industry? While there is no uniform response, quite often the response is: our purpose is not to alleviate poverty; we are not responsible for socio-economic rights; we are a profit making entity required to keep costs low and maximize profits for our shareholders. This is a status quo response, which is part of the capitalist political economic structure. It is not the purpose of this article to critique this system (although it is the view of the author that this system requires deep critique and review if we are to alleviate structural poverty). Rather, the purpose of this article is to show the disjuncture between the proposition by the extractives industry that mining is good for development, and the harsh reality that besets affected and sending communities, and the workers who sustain the mine.

As things stand, in most mining communities in developing countries, there is a level of dissatisfaction, disaffection and destabilization. ${ }^{126}$ While the popular narrative is that miners unreasonably demand higher wages that are neither sustainable nor proportionate to the worth of labour, there is a counter-narrative. This counter-narrative is that, while it is true that profits in mining often oscillate around volatile global valuation, wages are always low, even when the value of the mineral being extracted is high. ${ }^{127}$ The counternarrative is that mining corporations seek out extractives opportunities where, inter alia, there are accessible minerals, labour costs are low and governance structures are weak. Mining companies enter a market with a beguiling proposal of jobs and local economic development. However, this narrative is rarely reflected in reality. How this is fixed and whether or not it is the obligation of the corporation to ameliorate impoverishment in Africa is an indisputably complex matter. But at the very least, the mining-linked economic development must be exposed as the stuff of fiction and mythology: compelling but as mythical as the gods of ancient Greece and the oracles of ancient Rome. Mining as an instrument of development and poverty reduction is indeed mythology.

\footnotetext{
126 Shell is a favourite example of exploitative business operations in the developing world. Kolk and Van Tulder, note 4, 798 .

127 For a discussion of volatile revenue, see Collier, note 1, 40.
} 